\title{
Critical Roles of Lysosomal Acid Lipase in Myelopoiesis
}

\author{
Peng Qu, ${ }^{* \dagger}$ William C. Shelley, ${ }^{\ddagger}$ \\ Mervin C. Yoder, ${ }^{\ddagger \S}$ Lingyan Wu, ${ }^{\text {TIl }}$ Hong Du, \\ and Cong $\mathrm{Yan}^{\star \dagger}$ \\ From the Center for Immunobiology, the Departments of \\ Pathology and Laboratory Medicine, ${ }^{\dagger}$ the Herman B. Wells \\ Center for Pediatric Research, ${ }^{\ddagger}$ and the Department of \\ Pediatrics, Indiana University School of Medicine, Indianapolis, \\ Indiana; ChongQing University, "T ChongQing, China; and the \\ Division of Human Genetics," Cincinnati Children's Hospital \\ Medical Center, Cincinnati, Ohio
}

Lysosomal acid lipase (LAL) is a key enzyme that cleaves cholesteryl esters and triglycerides to generate free fatty acids and cholesterol in lysosomes. Genetic ablation of the lal gene $\left(\mathrm{lal}^{-/-}\right)$in mice has resulted in a systemic increase of macrophages and neutrophils, causing severe inflammation and pathogenesis in multiple organs. We hypothesized that aberrant growth and differentiation of myeloid cells in lal $^{-/-}$mice arises from dysregulated production of progenitor cells in the bone marrow. Indeed, lal $^{-/-}$ mice displayed increased numbers of primitive $\operatorname{lin}^{-} \mathrm{Sca}-\mathbf{1}^{+} \mathrm{C}-\mathrm{Kit}^{+}$(LSK) cells and granulocyte-macrophage precursors (GMP). Increased high proliferative potential colony-forming cells (HPP-CFC) were enumerated from cultured $l a l^{-/-}$bone marrow cells, as were significantly more CFU-GM, CFU-G, and CFU-M colonies. As a consequence, $\mathrm{lal}^{-/-}$mice developed significant myeloid infiltration, particularly with $\mathrm{CD11b}^{+} / \mathrm{Gr}^{+} \mathrm{1}^{+}$myeloid-derived suppressive cells in multiple organs. Both decreased apoptosis and increased proliferation contribute to the systemic increase of myeloid cells in $\mathbf{l a l}^{-/-}$myeloid cells. These lal $^{-/-} \mathrm{CD11b}^{+} / \mathrm{Gr}^{+} \mathbf{1}^{+}$cells displayed suppressive activity on $\mathrm{T}$ cell proliferation and function in vitro. Bone marrow chimeras confirmed that the myeloproliferative disorder in $\mathbf{l a l}^{-/-}$mice was primarily attributable to autonomous defects in myeloid progenitor cells, although the hematopoietic microenvironment in the $\mathrm{lal}^{-/-}$mice did not support hematopoiesis normally. These results provide evidence that LAL is an important regulator of myelopoiesis during hematopoietic development, differentiation, and homeostasis. (Am J Patbol 2010, 176:2394-2404; DOI: 10.2353/ajpath.2010.091063)

Hematopoietic stem cells possess the capacity for selfrenewal and the ability to differentiate into all lineages of mature hematopoietic cells. ${ }^{1}$ The production of mature blood cells requires the sequential proliferation and differentiation of hematopoietic stem cells through a successive series of increasingly lineage-restricted intermediate progenitors including common lymphoid progenitors (CLPS), common myeloid progenitors (CMPs), granulocyte-macrophage progenitors (GMPs), and the megakaryocyte-erythroid progenitors (MEPs). ${ }^{2}$ Because bone marrow-derived myeloid cells and lymphoid cells are effectors of inflammation and tissue remodeling in many organs, elucidating the molecular mechanisms governing hematopoiesis during the process of lineage commitment and lineagespecific expansion is critical for understanding inflammation-induced tissue damage and disease formation.

Lysosomal acid lipase (LAL) is a lysosomal hydrolase. It hydrolyzes cholesteryl esters and triglycerides in the lysosome of cells to generate free cholesterol and free fatty acids. Ablating $L A L\left(/\left.a\right|^{-1-}\right)$ in mice led to severe pathogenic phenotypes in multiple organs, including the adult liver, lung, spleen, adrenal glands, and small intestine..$^{3-5}$ These pathogenic changes in $\mid \mathrm{al}^{-1-}$ mice were highly associated with infiltration of macrophages and neutrophils, ${ }^{3,6,7}$ suggesting that LAL plays a critical role in regulating the development, differentiation, and/or proliferation of myeloid lineage cells. This was supported

Supported by National Institute of Health grants CA138759 (to C.Y.), HL087001 (to H.D.), HL-061803, HL-067862 (to C.Y. and H.D.), HL63169, and Al080759 (to M.Y.)

Accepted for publication January 19, 2010

Supplemental material for this article can be found on http://ajp. amjpathol.org.

Address reprint requests to Cong Yan, Ph.D., The Center for Immunobiology, Department of Pathology and Laboratory Medicine, Indiana University School of Medicine, Walther Hall C418, 980 W Walnut Street, Indianapolis, IN 46202; or Hong Du, Ph.D., Division of Human Genetics, Cincinnati Children's Hospital Medical Center, 3333 Burnet Ave., Cincinnati, OH 45229-3039. E-mail: coyan@iupui.edu or hong.du@ cchmc.org. 
by an observation that genetic intercross of a conditional transgenic mouse model in which LAL was specifically expressed in myeloid lineage cells with $\mid \mathrm{al}^{-/-}$mice led to amelioration of the systemic inflammation and tissue pathogenesis. ${ }^{6}$

To fully understand the dysregulated production of myeloid cells that are involved in $\mid \mathrm{al}^{-1-}$ disease formation, it is essential to elucidate the role of LAL in hematopoiesis. Our present results have revealed that LAL deficiency causes hematopoietic cell-intrinsic defects leading to profound blood phenotypes, especially an enhancement in $\mathrm{CD}_{11} \mathrm{~b}^{+} / \mathrm{Gr}-1^{+}$myeloid cells. LAL deletion in mice altered the frequency and the number of primitive IL7R ${ }^{-} \mathrm{Lin}^{-} \mathrm{Sca}-1^{+} \mathrm{C}^{-\mathrm{Kit}^{+}}$(LSK), CMP, GMP, and MEP populations in the bone marrow and changed myeloid cell distribution in the bone marrow, peripheral blood, spleen, and distal organs (eg, lung). When LAL deficient hematopoietic progenitor cells were assessed in clonogenic assays, significant increases in the numbers of myeloid colony forming cells (CFCs) were enumerated. Both hematopoietic progenitor cell defects and a microenvironmental change in $/ \mathrm{al}^{I^{-1-}}$ mice contributed to the above phenotype in bone marrow transplantation studies. These results demonstrate that neutral lipids and lipid mediators play important roles in normal myelopoiesis and contribute to abnormal inflammatory responses and disease formation in $|a|^{-1-}$ mice.

\section{Materials and Methods}

\section{Animal Care}

All scientific protocols involving the use of animals in this study have been approved by the Institution Animal Care and Usage Committee (IACUC) of Indiana University School of Medicine (Indianapolis, IN) and followed the guidelines established by the Panel on Euthanasia of the American Veterinary Medical Association. Protocols involving the use of recombinant DNA or biohazard materials have been approved by the Institutional Biosafety Committee and followed the guidelines established by the National Institutes of Health. Animals were housed under IACUC-approved conditions in a secured animal facility at Indiana University School of Medicine and were regularly screened for common pathogens. Experiments involving animal sacrifice used an approved $\mathrm{CO}_{2}$ narcosis protocol.

\section{Flow Cytometry}

Fluorescence activated cell sorting (FACS) analysis was performed on the bone marrow, peripheral blood, spleen and lung cells. Peripheral blood cells were incubated in red blood cell lysis buffer (BD Pharmingen, San Diego, $\mathrm{CA}$ ) for 10 minutes at room temperature. The cells were washed twice and resuspended in FACS buffer (PBS, $2 \%$ fetal bovine serum, $0.01 \%$ sodium azide), divided into aliquots, and placed in tubes. Bone marrow, spleen, and lung single cell suspensions were prepared as previously described. ${ }^{8}$ Approximately 1 to $2 \times 10^{6}$ cells from various organs in FACS buffer were blocked with FcR blocking antibodies (BD Pharmingen, San Diego, CA) followed by incubation with isotype control or primary antibodies. For 6-color hematopoietic stem cell and hematopoietic progenitor analysis and sorting, ${ }^{1}$ color compensation samples were produced by singly staining bone marrow cells with one antibody of each of 6 fluorochromes. Lineage markers (biotin-CD3, -CD4, -CD8, -Mac-1, -Gr-1, -Ter119, and -B220) and other marker antibodies (Sca-1, C-Kit, IL7R $\alpha$, and CD34) were purchased from BD Biosciences (San Jose, CA). Anti-CD16/32, anti-CD11C (N148), antiCD11b (M1/70), anti-Gr-1 (RB6-8c5), anti-CD4 (GK1.5), anti-CD45.1 (A20), anti-CD45.2 (104) anti-CD8 (53-6.7), and anti-B220 (RA3-6B2) were purchased from e-Biosciences (San Diego, CA). Cells were analyzed on a LSRII machine (BD Biosciences, San Jose, CA). Data were analyzed using the BD FACStation Software (BD Biosciences). The total number of positive cells was calculated as the percentage of total gated viable cells. Quadrants were assigned using isotype control mAb.

For measurement of intracellular signaling molecules, the assays were performed according to the protocols previously described. ${ }^{8}$ Briefly, after surface staining, cell suspensions from the bone marrow, blood, spleen, and lung were fixed with $2 \%$ formaldehyde. Fixation samples were resuspended in methanol at a final $90 \%$ concentration. Finally, samples were washed and resuspended in $1 \times$ PBS containing $4 \%$ fetal bovine serum (FBS) at $10^{6}$ cells in $100 \mu \mathrm{l}$. Cell suspensions were labeled with the primary phosphospecific antibodies for 30 minutes at room temperature, then washed in PBS containing 4\% FBS and labeled using the secondary antibody. After washing, samples were analyzed on a LSRII machine (BD Biosciences). Data of percentage cell numbers and mean fluorescence intensity (MFI) were analyzed using the BD FACStation Software (BD Biosciences). Quadrants were assigned using isotype control. Anti-PU.1 antibody, anti-phospho-Erk, P38, and Stat3 were purchased from Cell Signaling Technology (Danvers, MA).

\section{Bone Marrow Transplantation}

Whole bone marrow cells were harvested from 8- to 12week-old male $\mathrm{lal}^{+/+}$or $\mathrm{lal}^{-1-}$ mice (CD45.2 congenic strain). Red blood cells were lysed in ASK buffer, and the remaining mononuclear cells were resuspended in sterile PBS. Total nucleated bone marrow cells $\left(5 \times 10^{6}\right)$ in 200 $\mu$ I PBS were injected intravenously into isoflurane-anesthetized 8-week-old $\mathrm{lal}^{+/+}$or $\mathrm{lal} \mathrm{I}^{-1-}$ recipients (CD45.1 congenic strain) that had been lethally irradiated with 1000 rad after 4 hours. Five to six months after transplantation, the bone marrow, peripheral blood, spleen, and lung from the chimeras were collected and stained with CD45.1 or CD45.2 (e-Biosciences) antibodies to verify donor-derived reconstitution (and lack of endogenous marrow recovery). ${ }^{9,10}$ FACS labeling of the cells and analysis were outlined as above.

\section{Colony-Forming Units-Spleen (CFU-S ${ }_{14}$ ) Assay}

Bone marrow cells from 3-month-old $\mid \mathrm{al}{ }^{+/+}$and $\mid \mathrm{al} \mathrm{l}^{-{ }^{-}}$ mice were injected into lethally irradiated wild-type mice. 
Early committed hematopoietic progenitors were determined by surface colony counting on the spleen of recipient mice at day 14 (CFU-S ${ }_{14}$ ) after bone marrow transplantation for macroscopic observation. ${ }^{11,12}$

\section{Progenitor Assays}

All assays were performed in duplicate according to the manufacturer's instruction (Stem Cell Technologies, Vancouver, BC, Canada). In general nucleated bone marrow cells $\left(5 \times 10^{4}\right)$ from 3 -month-old $\mathrm{lal}^{+/+}$and $\mathrm{lal}{ }^{-1-}$ mice were plated in $2.5 \mathrm{ml}$ methylcellulose media (MethoCult 3434) supplemented with a cocktail of recombinant cytokines and placed in a humidified chamber with $6 \% \mathrm{CO}_{2}$ at $37^{\circ} \mathrm{C}$. Colonies containing at least 50 cells were scored on day 7 of culture. In CFU-GM experiments, granulocyte-macrophage colony-stimulating factor (GM-CSF) (10 ng/ml), leukemia inhibitory factor (LIF, $10 \mathrm{ng} / \mathrm{ml})$, vascular endothelial growth factor (VEGF, $50 \mathrm{ng} / \mathrm{ml}$ ), interleukin (IL)-11 (100 ng/ml), FLT 3L (10 ng/ml), and thrombopoietin $(5 \mathrm{ng} / \mathrm{ml})$ were added. All growth factors were obtained from R\&D System. For the CSF-1-dependent CFU (CFU-M) assay, Methocult (M3231; containing serum with no additional growth factors) was supplemented with $100 \mathrm{ng} / \mathrm{ml}$ mouse macrophage colony-stimulating factor (M-CSF) (R\&D systems), and cells were incubated for 10 days. The identity of the colony types was scored visually. For the G-CSF-dependent CFU (CFU-G) assay, $5 \times 10^{4}$ nucleated bone marrow cells were cultured in methycellulose supplemented with recombinant murine G-CSF at concentration of $10 \mathrm{ng} / \mathrm{ml}$. Cells were cultured in duplicate for each concentration at $37^{\circ} \mathrm{C}$ and $5 \% \mathrm{CO}_{2}$ for 10 days, after which colony numbers were scored. Erythroid precursors were determined by burst forming unit-erythroid (BFU-E) counting, as previously described. ${ }^{13}$

For generation of high-proliferative potential colonyforming cells (HPP-CFC), double-layer agar HPP-CFC cultures were prepared as previously described. ${ }^{11}$ Briefly, bone marrow cells were seeded in $35-\mathrm{mm}$ gridded tissue culture dishes at $5 \times 10^{4} / \mathrm{ml}$ in methylcellulose media containing the growth factors $\mathrm{IL}-1 \alpha(1000 \mathrm{units} / \mathrm{ml})$, IL-3 (200 units/ml), M-CSF (1000 units/ml), and kit ligand (50 ng/ml; Stem Cell Technologies, Vancouver, BC, Canada), followed by the addition of $1 \mathrm{ml}$ of $0.5 \%$ agar (Bacto-agar; Difco). HPP-CFCs were defined as colonies with a diameter greater than $1 \mathrm{~mm}$, whereas LPPCFCs were defined as colonies with a diameter smaller than $0.5 \mathrm{~mm}$ using an inverted microscope.

\section{Histology of the Lung}

The lungs from $|\mathrm{al}|^{+/+}$and $|\mathrm{al}|^{-1-}$ mice were infused with a fixative solution ( $4 \%$ paraformaldehyde, $1 \times$ phosphatebuffered saline) and were dissected out and stored in fixative at $4^{\circ} \mathrm{C}$ for $\approx 24$ hours. After fixation and embedding in paraffin, lung tissue sections were cut to a $5-\mu \mathrm{m}$ thickness. The adult lung slides were baked at $60^{\circ} \mathrm{C}$ for 2 hours and washed in a series of xylene and ethanol rinses to remove paraffin from the tissues. Multiple sections from each lung were stained with hematoxylin and eosin.

\section{Bromodeoxyuridine Incorporation}

For cell proliferation determination, $|\mathrm{la}|^{+/+}$and $|\mathrm{al}|^{-1-}$ littermates were inoculated i.p. with $1 \mathrm{mg}$ bromodeoxyuridine (BrdU) per animal (Sigma-Aldrich) in PBS every 12 hours for up to 2 days. Cells from different organs were harvested and stained with surface markers as mentioned above. Labeled cells were washed twice with PBS and detected for BrdU with a BrdU flow kit (BD BioSciences). Cells were incubated with DNase I and washed again followed by staining with fluorescein-anti-BrdU antibody before analysis on the LSR II (as described above).

\section{Annexin V Binding}

The apoptotic cell population was determined by fluorescein isothiocyanate-labeled-Annexin V (FITC-annexinV) and 7-AAD staining (Apoptosis Detection Kit; BD PharMingen, Bedford, MA). Cells from different tissues of $/ a^{+/+}$ and $|\mathrm{a}|^{-1-}$ mice were stained with antibodies to surface markers and washed twice with PBS. After resuspension of labeled cells in Annexin $\mathrm{V}$-binding buffer containing FITC-conjugated Annexin V (1:50 dilution), 7-AAD was added into samples for 10 minutes incubation on ice. Control cells stained with Annexin V-FITC or 7-AAD alone were used to compensate for the flow cytometric analysis. Annexin V and PI double-negative cells were defined as live cells. Nonspecific binding was blocked by preincubating the cells with rat IgG $(10 \mu \mathrm{g} / \mathrm{ml})$ and anti-Fcll/III (as noted above). Cells were analyzed on the LSRII machine within one hour.

\section{Kwik-Diff Staining of Bronchioalveolar Larvage Fluid and White Blood Cells}

Bronchioalveolar larvage fluid was collected by $1 \mathrm{ml} 1 \times$ PBS wash and repeated three times. Cells were centrifuged at $1000 \mathrm{rpm}$ for 5 minutes and resuspended into $0.5 \mathrm{ml} 1 \times$ PBS . Total cell numbers in bronchio-alveolar larvage fluid were determined by hemo-cytometery. The same volume of cell suspension $(0.125 \mathrm{ml})$ was cytospun on the slide and stained with the Kwik-Diff stain kit (Thermo Shandon, Pittsburgh, PA). Whole blood was collected and the red blood cells were destroyed by using "Red blood cell lysing buffer" (Sigma, St. Louis, MO). The white blood cells were counted and cyto-spun on the slide and stained with the Kwik-Diff stain kit.

\section{Blood Count}

Peripheral blood was collected in ethylenediaminetetraacetic acid (EDTA)-coated tubes following retro-orbital puncture (Becton Dickinson, Franklin Lakes, NJ). Complete blood counts were determined with a Hemavet 950FS hematology analyzer through Herman B Wells Center for Pediatric Research, Indiana University. 
A
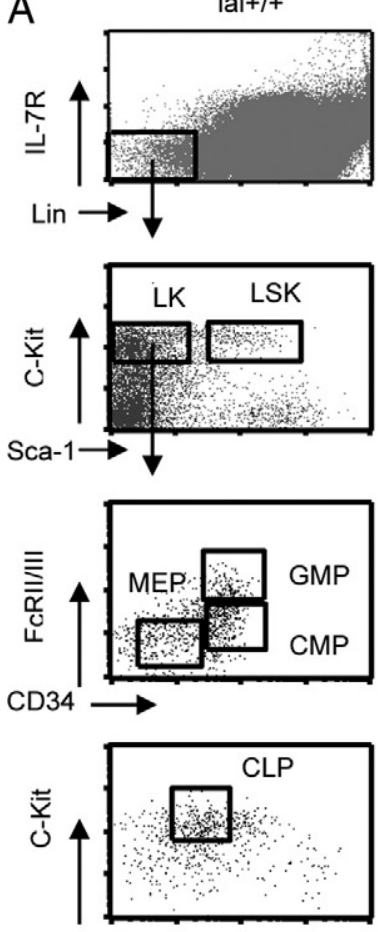

Sca-1 $\longrightarrow \quad($ Lin-/IL-7R+)

C

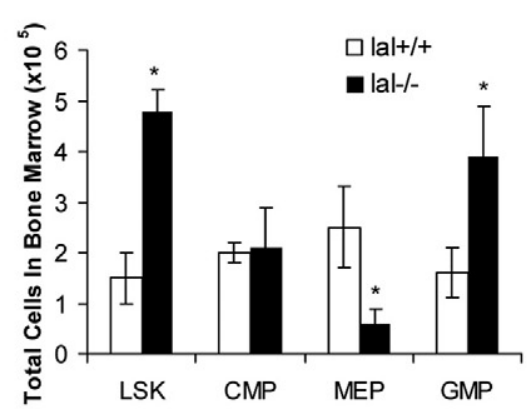

lal-/-
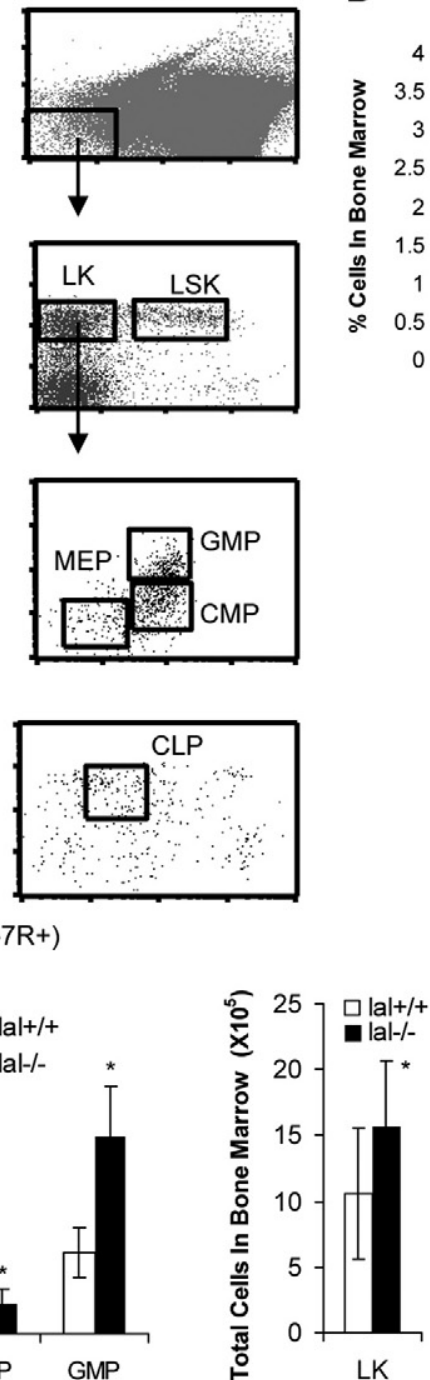

GMP

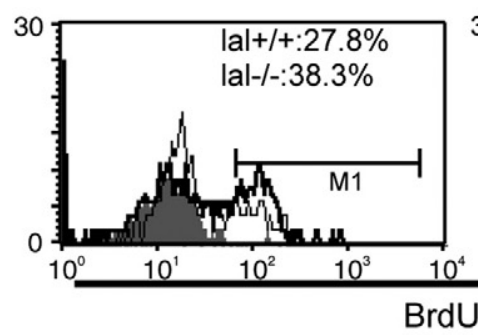

B
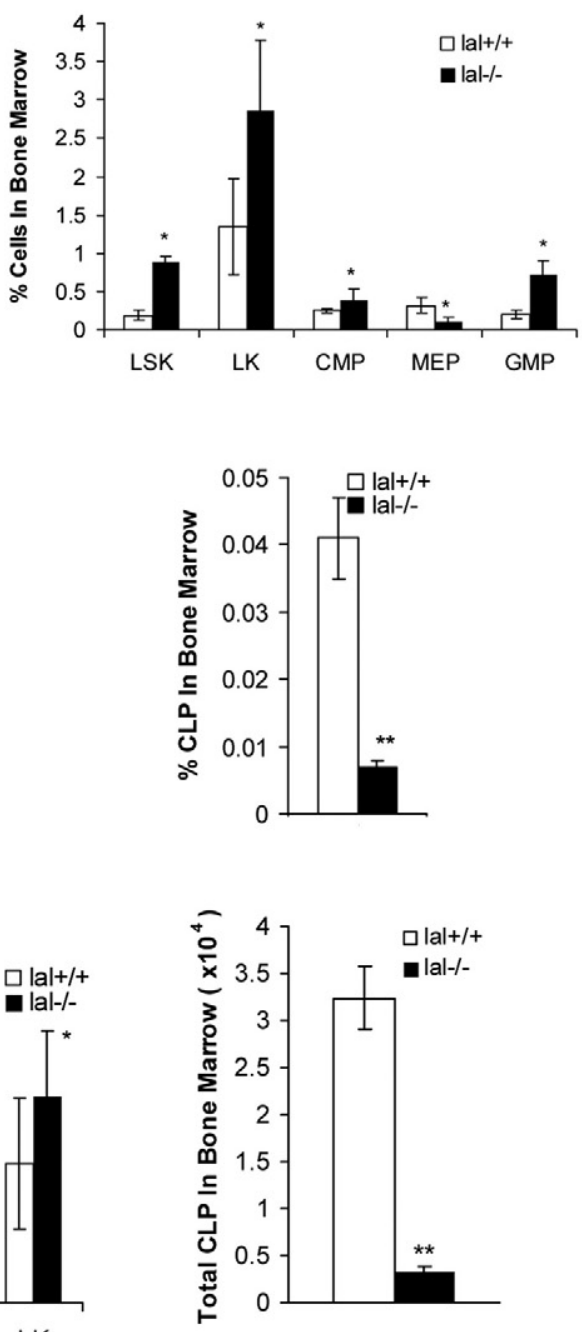

MEP

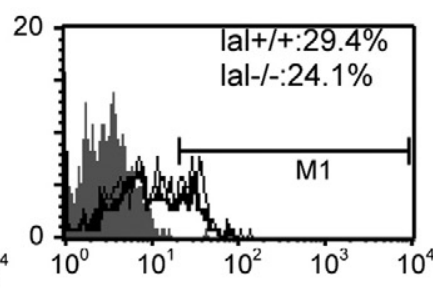

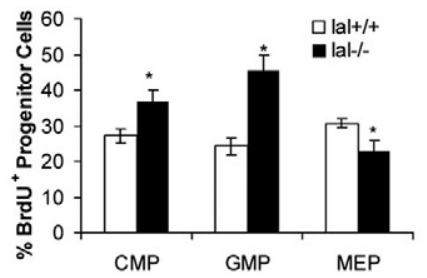

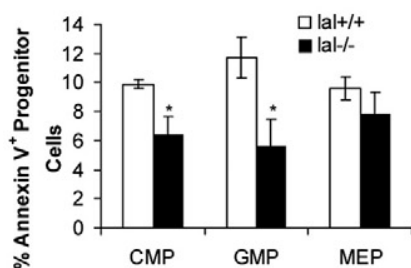

Figure 1. LAL deficiency affects hematopoietic progenitor populations. A: Representative FACS profiles of progenitor populations, including LSKs, LKs, CMPs, MEPs, GMPs, and CLPs from the bone marrow of $\mathrm{lal}^{++}$or $l a l^{-1}$ mice at 3 months old. The gating strategy is described in Materials and Methods. B and $\mathbf{C}$ : The percentages and total numbers of LSK, LK, CMP, MEP, GMP, and CLP populations in the bone marrow of lal ${ }^{+/+}$and lat ${ }^{-/-}$mice are calculated according to $\mathbf{A}$ by flow cytometry. Values were derived from four mice of each groups $(n=4) .{ }^{*} P<0.05 ;{ }^{* * *} P<0.01$. D: Proliferation and apoptosis of bone marrow progenitor cells were measured by BrdU and Annexin V labeling in gated areas of progenitor cells. Values were derived from four mice of each groups $(n=4)$. ${ }^{*} P<0.05$. A representative of BrdU FACS analysis is presented. LK indicates IL7R $\alpha^{-} \mathrm{Lin}^{-} \mathrm{C}-\mathrm{Kit}^{+} \mathrm{Sca}-1^{-}$progenitors; LSK, Lin ${ }^{-} \mathrm{Sca}-1^{+} \mathrm{C}-\mathrm{kit}{ }^{+}$progenitors; CMP, common myeloid progenitors; GMP, granulocyte-monocyte progenitors; MEP, megakaryocyte-erythroid progenitor; CLP, common lymphoid progenitors. 


\section{Transmission Electronic Microscopy}

White blood cells from the peripheral blood were fixed at $4^{\circ} \mathrm{C}$ overnight and embedded in Epon-Araldite (Electron Microscopy Sciences, Hatfield, PA). Ultrathin sections were stained with uranyl acetate and lead citrate and examined with electron microscope by the EM Core Facility in the Department of Pathology and Laboratory Medicine, Indiana University School of Medicine, Indianapolis.

\section{Statistical Analysis}

A paired Student $t$ test or analysis of variance was used to evaluate the significance of the differences among study groups. Statistical analysis was performed with SPSS version 11.5, with a value of $P<0.05$ regarded as statistically significant.

\section{Results}

\section{Effect of LAL Deficiency on Hematopoietic Progenitor Populations in the Bone Marrow}

To dissect the effect of lal gene deletion on progenitor populations in the bone marrow, we analyzed $/ \mathrm{al}^{-1-}$ mice at 3 months of age for the percentage and absolute numbers of LSK (IL7R $\left.\alpha^{-} \mathrm{Lin}^{-} \mathrm{Sca}-1^{+} \mathrm{C}_{-} \mathrm{Kit}^{+}\right), \quad \mathrm{LK} \quad\left(\mathrm{IL7R} \alpha^{-} \mathrm{Lin}^{-}{ }^{-}{ }^{-}\right.$ $\mathrm{Kit}^{+} \mathrm{Sca}-1^{-}$), CMP (IL7R $\alpha^{-} \mathrm{Lin}^{-} \mathrm{Sca}-1^{-} \mathrm{C}_{-} \mathrm{Kit}^{+} \mathrm{CD} 34^{+} \mathrm{FCRII} /$ III low $)$, GMP (IL7R $\left.\alpha^{-} \mathrm{Lin}^{-} \mathrm{Sca}-1^{-} \mathrm{C}_{-} \mathrm{Kit}^{+} \mathrm{CD} 34^{+} \mathrm{FCRII} / \mathrm{III}^{+}\right)$, and MEP (IL7R $\alpha^{-} \mathrm{Lin}^{-} \mathrm{Sca}-1^{-} \mathrm{C}^{-} \mathrm{Kit}^{+} \mathrm{CD} 34^{-} \mathrm{FCRII} / \mathrm{III}{ }^{-}$) populations. ${ }^{1} \mathrm{LAL}$ deficiency resulted in significant increases in LSK and LK stem/progenitor cell populations in the bone marrow (Figure 1, A-C). The CMP frequency and number were modestly increased, whereas the frequency and number of GMP were doubled compared with the corresponding wild-type compartments (Figure 1). In parallel, the frequency and number of MEPs were decreased by more than twofold in the bone marrow of $\mathrm{all}^{-1-}$ mice (Figure 1). These results suggest that LAL deficiency leads to a significant increase in the phenotypic populations that contain stem/progenitor cells committing to myeloid lineage with a selective expansion of LSK and GMPs, but a decrease in MEP. Similarly, the common lymphoid progenitor (CLP: IL-7R ${ }^{+} \mathrm{Lin}^{-} \mathrm{Sca}-1^{\text {int }} \mathrm{C}-\mathrm{Kit}^{\mathrm{int}}$ ) frequency and number were significantly decreased, consistent with our recent findings on lymphocyte development and maturation in lal ${ }^{-1-}$ mice ${ }^{9}$ and with the present observations of a progenitor production skewing toward the myeloid lineage. To assess whether increased CMP and GMP in $\mid a l^{-1-}$ mice were attributable to cell proliferation, $\mid a l^{+/+}$and $\mid a l^{-1-}$ mice were injected intraperitoneally with BrdU. BrdU-positive cells in CMP, GMP, and MEP populations were gated and analyzed by FACS. As demonstrated in Figure 1D, the $\mathrm{BrdU}^{+} \mathrm{CMP}$ and GMP populations were increased whereas the $\mathrm{BrdU}^{+} \mathrm{MEP}$ population was decreased in $/ a l^{-1-}$ mice. In contrast, the apoptotic activity in CMP and GMP, populations by Annexin $V$ labeling and FACS analysis was decreased whereas the apoptotic activity in the BrdU ${ }^{+}$MEP popu- lation remained relatively unchanged in $/ \mathrm{I}^{-1-}$ mice (Figure 1D). Therefore, LAL deficiency stimulated proliferation and inhibited apoptosis in myeloid progenitor cells in the bone marrow.

\section{Effects of LAL Deficiency on Bone Marrow Hematopoietic Colony Forming Cells}

CFU-S assays were performed on $l a l^{+/+}$and $l a l^{-1-}$ mice to determine the effects of $L A L$ deficiency on primitive hematopoietic progenitor cells. Approximately $1 \times 10^{5}$ nucleated bone marrow cells from $\mathrm{lal}^{+/+}$and $\mathrm{lal}^{-1-}$ mice
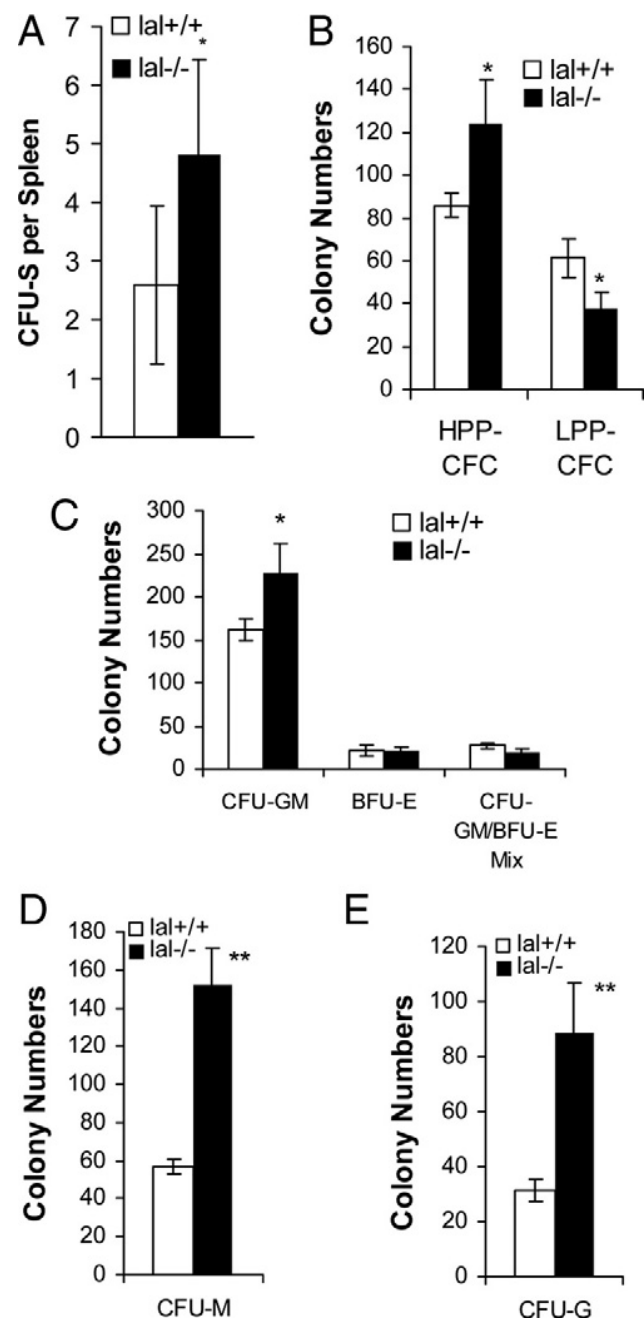

Figure 2. Increased differentiation of progenitor cells in $\mathrm{lat}^{-1}$ mice. A: Recipient wild-type mice (CD45.1) were transplanted with bone marrow cells from $\mathrm{lal}^{+/+}$and $\mathrm{lal}^{-/-}$mice (CD45.2). CFU-S colony formation on the spleen surface of recipient mice was counted 14 days after transplantation. The frequency of committed progenitor colonies (CFU-S ${ }_{14}$ ) in $\mathrm{lal}^{+/+}$and $\mathrm{lal}^{-1}$ bone marrow is shown as the mean $\pm \mathrm{SD}$ and represents the results of three experiments $(n=5)$. ${ }^{*} P<0.05$. B: The frequency of HPP-CFC in $l a l^{+/+}$and $\mathrm{lal}^{-1}$ bone marrow is shown as the mean \pm SD and represents the results of four experiments $(n=4) .{ }^{*} P<0.05$. C: The frequency of macrophage and granulocyte progenitor cells (CFU-GM) in $\mathrm{lal}^{+/+}$and $\mathrm{lal}^{-/-}$bone marrow is shown as the mean \pm SD and represents the results of three experiments $(n=3) .{ }^{*} P<0.05$. D: Macrophage colony formation in $5 \times 10^{4}$ bone marrow cells from $\mathrm{lal}^{+/+}$and $\mathrm{lal}^{-/-}$mice in methylcellulose containing $100 \mathrm{ng} / \mathrm{ml}$ $\mathrm{M}-\mathrm{CSF}$. Colonies were sorted at day 10 . Results are mean $\pm \mathrm{SD},{ }^{* *} P<0.01$ E: Granulocyte colony formation in $5 \times 10^{4}$ bone marrow cells from $\mathrm{lal}^{+/+}$ and $\mathrm{lal}^{-/-}$mice in methylcellulose containing $10 \mathrm{ng} / \mathrm{ml} \mathrm{G}$-CSF. Colonies were sorted at day 10 . Results are mean $\pm \mathrm{SD},{ }^{* *} P<0.01$. 

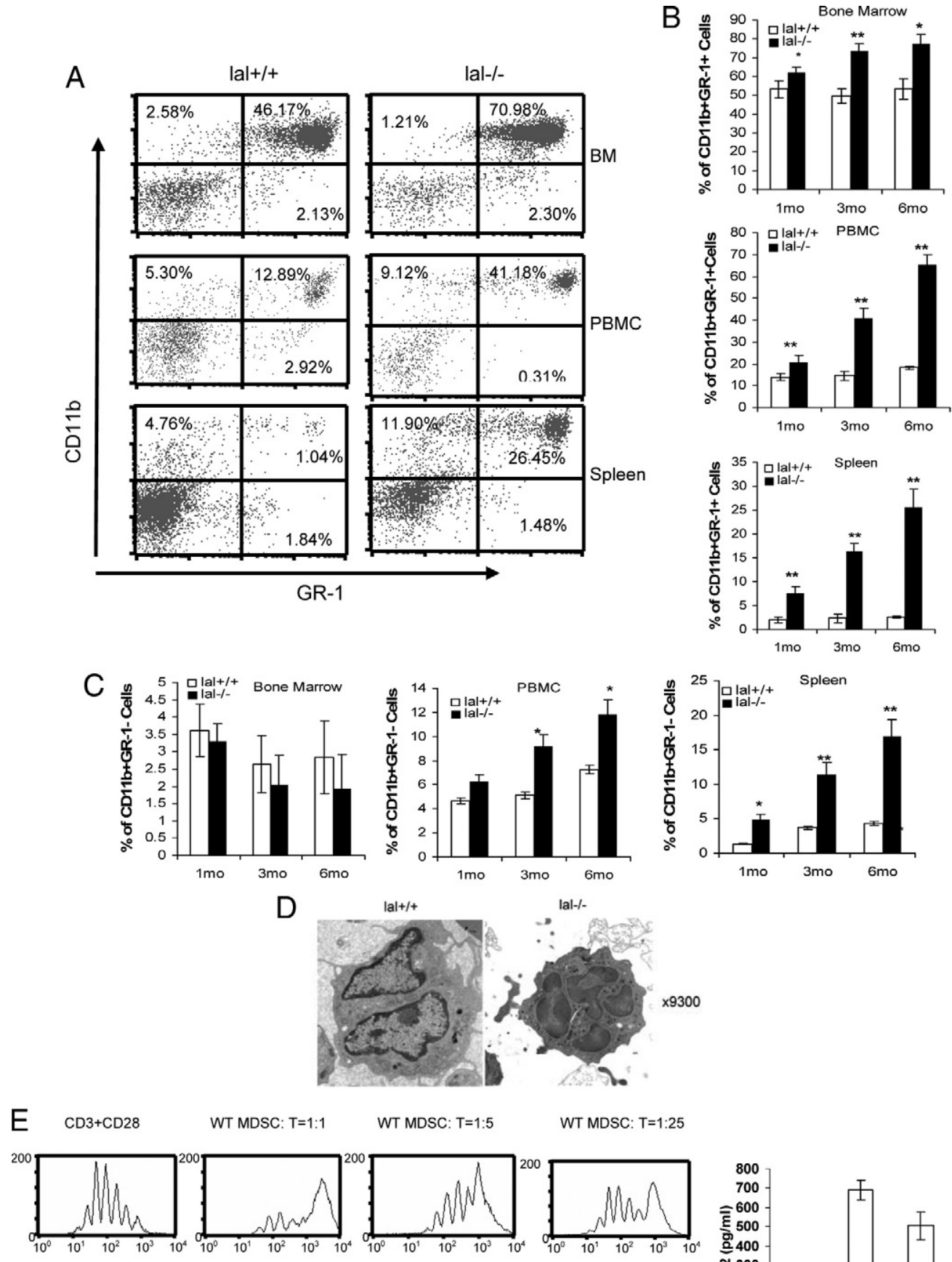

WT MDSC: $T=1: 1$

WT MDSC: $T=1: 5$

WT MDSC: $T=1: 25$
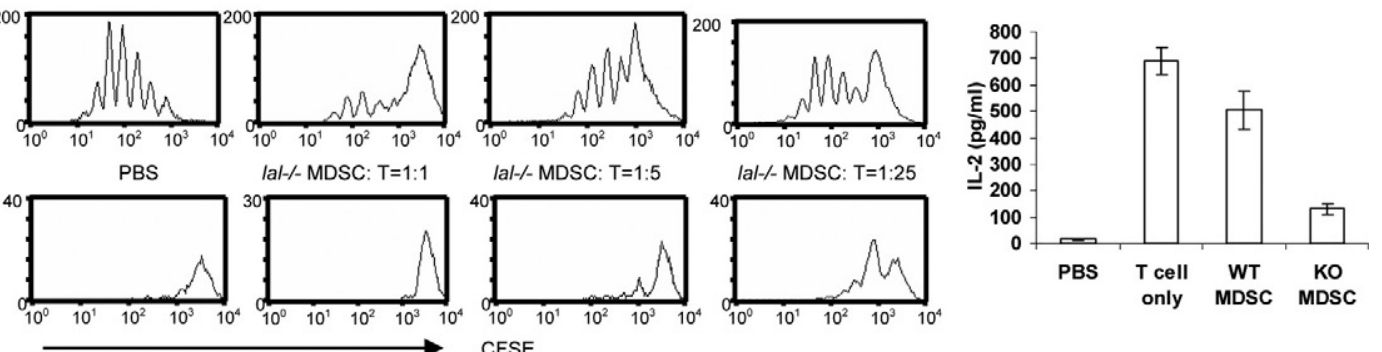

Figure 3. Systemic expansion and accumulation of myeloid cells in $l a l^{-1}$ mice. A: Representative FACS analysis of bone marrow (BM), peripheral blood (PBMC), and spleen from 3-month-old $\mathrm{lal}^{+/+}$and $\mathrm{lat}^{-1-}$ mice by CD11b and GR-1 antibody staining. B: The percentage number of CD11b ${ }^{+} / \mathrm{GR}^{+} 1^{+}$double-positive cells in the bone marrow, blood, and spleen of $l a l^{+/+}$and $\mathrm{lal}^{-1-}$ mice at 1,3 , and 6 months old from five independent experiments $(n=5)$. C: The percentage number of $\mathrm{CD} 11 \mathrm{~b}^{+} / \mathrm{GR}-1^{-}$cells in the bone marrow, blood, and spleen of $l a l^{++}$and $l a l^{-1}$ mice at 1,3 , and 6 months old from five independent experiments $(n=5$ ). Results in $\mathbf{B}$ and $\mathbf{C}$ were mean $\pm \mathrm{SD},{ }^{*} P<0.05$; ${ }^{* *} P<0.01$. D: Morphological analysis of peripheral blood neutrophils by transmission electron microscopy (original magnification, $\times 9300$ ). E: CFSE labeled wild type CD ${ }^{+}$T cells were stimulated with anti-CD3 mAb plus anti-CD28 mAb for 4 days in the presence or absence of $\mathrm{CD} 11 \mathrm{~b}^{+} / \mathrm{Gr}_{-} 1^{+}$cells isolated from the spleens of wild-type mice (wild-type MDSCs) or lat ${ }^{-/-}$mice (lat ${ }^{/-}$MDSCs) at different ratios between MDSC: $\mathrm{CD}^{+}{ }^{+} \mathrm{T}$ cells. Proliferation of labeled $\mathrm{CD} 4^{+} \mathrm{T}$ cells was analyzed by FACS. Peaks represent cell division cycles. PBS was negative control. The concentrations of secreted IL- 2 in the cultured medium were measured by ELISA. $n=4$. 
(CD45.2) were transplanted into irradiated $\mid \mathrm{lal} \mathrm{I}^{+/+}$mice (CD45.1). CFU-Ss were counted in the recipient spleens on day 14. More CFU-S per spleen were found in the recipient mice injected with bone marrow cells from $/ \mathrm{al}^{-/-}$ mice than those injected with $/ \mathrm{al} \mathrm{I}^{+/+}$bone marrow (Figure 2A). FACS analyses revealed that CFU-S colonies in the spleen of recipient mice expressed the donor-type CD45.2 antigen (data not shown).

Hematopoietic progenitor cells committed to the myeloid lineage hierarchy were assessed in the $\mathrm{Ia} \mathrm{I}^{+/+}$and $\mid \mathrm{al} \mathrm{I}^{-1-}$ bone marrow cells by in vitro CFC assays. The most primitive CFC identified by in vitro culture is the high proliferative potential-colony forming cell (HPP-CFC). ${ }^{11,14}$ LAL deficiency enhanced the colony frequency of HPPCFCs in response to several combinations of cytokines as outlined in Materials and Methods (Figure 2B). In contrast, there was a significant decrease on the colony frequency of low proliferative potential-colony forming cells (LPP-CFC).

Culturing $/ \mathrm{al}{ }^{-1-}$ bone marrow cells in the CFU-GM assay, which measures activity of more committed myeloid progenitor cells, revealed an increased frequency of GMCFC compared with the frequency measured from bone marrow cells of $\mid \mathrm{al}^{+/+}$mice (Figure $2 \mathrm{C}$ ). The frequency of BFU-E and mixed lineage CFC was not significantly different between cells isolated from $\mathrm{lal}^{-1-}$ and wild-type mice.

To further assess how LAL deficiency affects myeloid differentiation in the bone marrow, $|\mathrm{al}|^{+1+}$ or $|\mathrm{lal}|^{-1-}$ bone marrow cells were grown in methylcellulose cultures with M-CSF or granulocyte colony-stimulating factor (G-CSF) to stimulate committed macrophage or granulocyte CFC formation. We counted two- to threefold more monopotent CFU-M and CFU-G in $\mid \mathrm{al}^{-{ }^{-}-}$bone marrow cells compared with those in $\mid \mathrm{al}{ }^{+/+}$bone marrow (Figure 2, D and E). In sum, LAL deficiency clearly enhances primitive and committed myeloid CFC formation in the bone marrow.

\section{LAL Deficiency Results in Myeloproliferative Disorder}

To analyze how hematopoietic progenitor defects in the bone marrow affects myelopoiesis in other organs, the populations of neutrophils and monocytes in the bone marrow, peripheral blood, and spleen were measured by flow cytometry with Gr-1 and CD11b antibody staining. Neutrophils typically express both CD11b and GR-1 on the cell surface, whereas monocytes express CD11b but little or no GR-1. ${ }^{15,16}$ Although $\mathrm{CD} 11 \mathrm{~b}^{-} / \mathrm{GR}-1^{+}$single positive cells were not significantly changed, CD11 $\mathrm{b}^{+} /$ GR-1- ${ }^{-}$single-positive cells were significantly increased in the blood $(9.12 \%$ vs $5.30 \%)$ and spleen $(11.90 \%$ vs $4.76 \%)$ of $\mathrm{Ial}^{-1-}$ mice compared with those of agematched $\mathrm{Ial}^{+/+}$mice (Figure 3A). More strikingly, $\mathrm{CD} 11 \mathrm{~b}^{+} / \mathrm{GR}-1^{+}$double-positive cells were dramatically increased in the blood (41.18\% versus $12.89 \%$ ) and spleen $(26.45 \%$ versus $1.04 \%)$ of $l a l^{-1-}$ mice compared with those of age-matched $l a l^{+/+}$mice, whereas the bone marrow $(70.98 \%$ versus $46.17 \%)$ showed a modest increase (Figure 3A). These cells were able to be released from the bone marrow and entered the circulating system
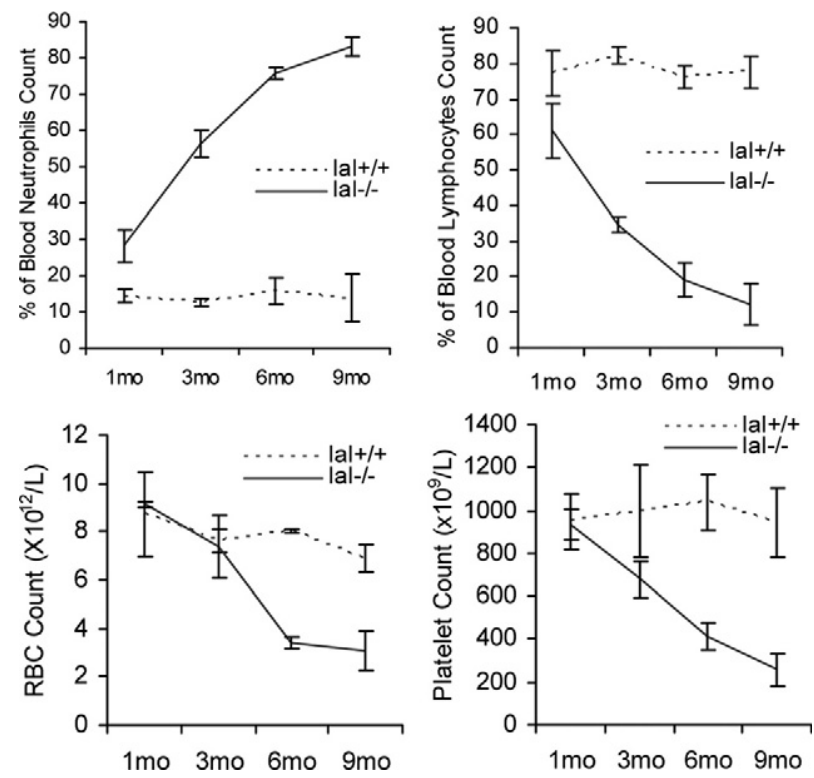

Figure 4. Counts of red blood cells, neutrophils, lymphocytes, and platelet in the blood. Red blood cells, lymphocytes, neutrophils, and platelets were counted from 1-, 3-, 6-, and 9-month-old $\mathrm{lal}^{+/+}$and $\mathrm{lal}^{-1-}$ mice. Results were mean $\pm \mathrm{SD}$.

and infiltrated the organs. With age progression, the percentage of $\mathrm{CD} 11 \mathrm{~b}^{+} / \mathrm{GR}-1^{-}$single-positive cells and CD $11 \mathrm{~b}^{+} / \mathrm{GR}-1^{+}$double-positive cells were steadily increased in the bone marrow, blood, and spleen in the mutant animals compared with wild-type controls (Figure 3, B and C). When examined by electron microscopy, nuclear hypersegmentation of leukocytes in peripheral blood was observed (Figure 3D). This abnormal sign of neutrophil maturation combined with the altered distribution of the immature neutrophilic phenotypes meets criteria of a myeloproliferative disorder in the older animals. It is surprising that the blood counts showed profound anemia, thrombocytopenia, and lymphopenia in older mice (Figure 4). Therefore, hematopoiesis in $\mid \mathrm{lal}^{-1-}$ mice is skewed toward the myeloid lineage at the expense of lymphoid and erythroid differentiation. Most LAL-deficient mice died at 8 to 9 months of age as a result of systemic multiorgan dysfunction as we previously reported. ${ }^{3-5} \mathrm{CD} 11 \mathrm{~b}^{+} /$ GR $-1^{+}$cells are also known as myeloid-derived suppressive cells (MDSCs) in disease condition. ${ }^{17-19}$ To show whether $\mathrm{CD} 11 \mathrm{~b}^{+} / \mathrm{GR}-1^{+}$cells possess immune suppressive function, CFSE-labeled wild-type $\mathrm{CD} 4^{+} \mathrm{T}$ cells were cultured in vitro and stimulated with anti-CD3 mAb plus anti-CD28 mAb in the presence or absence of MDSCs from wild-type mice or lal ${ }^{-1-}$ mice. Proliferation of $\mathrm{CD} 4^{+} \mathrm{T}$ cells was evaluated for CFSE dilution (cell division). CD11 $\mathrm{b}^{+} /$ GR- $1^{+}$cells from $|a|^{-1-}$ mice showed the strongest inhibition on proliferation of wild-type T cells after anti-CD3 mAb plus anti-CD28 mAb stimulation, whereas $\mathrm{CD} 11 \mathrm{~b}^{+} / \mathrm{GR}-1^{+}$cells from wild-type mice showed the modest inhibition on proliferation of wild-type T cells at a higher ratio (1:1). In addition, release of lymphokine IL-2 from T cells was significantly reduced when cocultured with $\mathrm{CD} 11 \mathrm{~b}^{+} / \mathrm{GR}-1^{+}$cells from $|a|^{-1-}$ mice, implicating a functional impairment of $\mathrm{CD}^{+}{ }^{+} \mathrm{T}$ cells (Figure 3E). 


\section{LAL Deficiency Results in Myeloid Cell Infiltration and Accumulation in the Lung}

In the lung of $|a|^{-1-}$ mice, inflammatory cell infiltration caused emphysema and epithelial hypercellularity with age progression. 3,7 To determine whether myeloid cells were accumulating in the lung, myeloid cells in the lung were measured by flow cytometry with $\mathrm{Gr}-1$ and CD11b antibody staining. In this assay, CD $11 \mathrm{~b}^{+} / \mathrm{GR}-1^{+}$cells increased more than sixfold in the lung $(26.90 \%$ versus $4.81 \%)$ of $\mathrm{lal}^{-/-}$mice compared with age-matched $/ \mathrm{al}{ }^{+/+}$mice (Figure $5 A)$. With age progression, the percentage of both $C D 11 b^{+} /$ GR $-1^{-}$and $\mathrm{CD} 11 \mathrm{~b}^{+} / \mathrm{GR}-1^{+}$myeloid cells were steadily increased in the $\mid \mathrm{al}^{-1-}$ lung (Figure $5 \mathrm{~B}$ ). In some areas, the $\mid \mathrm{al}^{-1-}$ lung was filled with inflammatory cells (Figure 5C). In the bronchioalveolar larvage fluid, Kwik-Diffy staining analysis demonstrated that most inflammatory cells in $\mathrm{lal}^{-1-}$

A

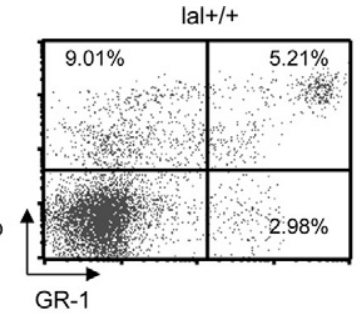

B

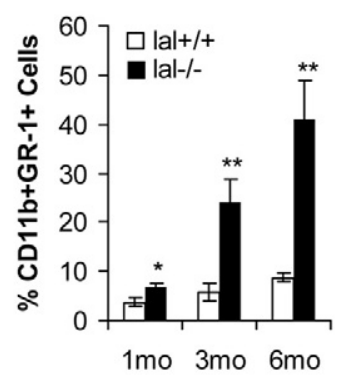

C

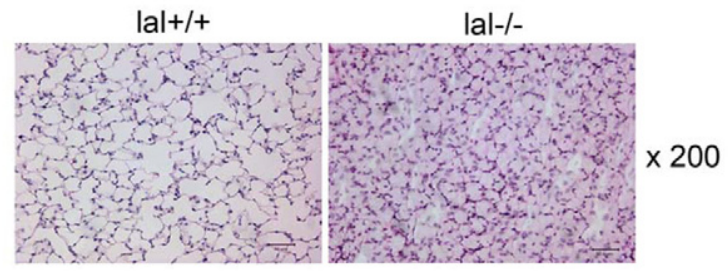

D

lal $+/+$

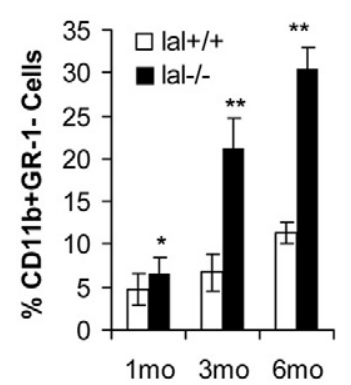

lal-/-

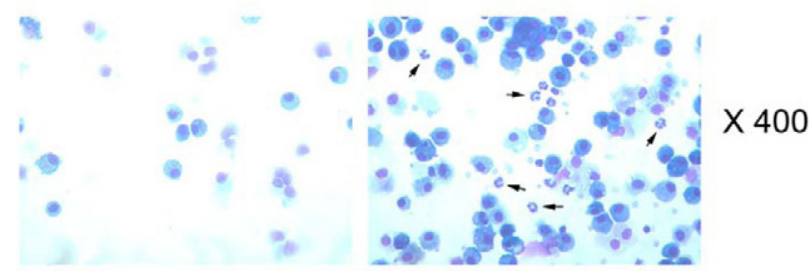

Figure 5. Myeloid cell infiltration in the $\mathrm{lal}^{-/-}$lung. A: Representative FACS analysis of whole lung cells from 3-month-old $\mathrm{lal}^{+/+}$and $\mathrm{lat}^{-/-}$mice by CD11b and GR-1 antibody staining. B: The percentage number of CD11b ${ }^{+}$ GR-1 ${ }^{+}$and $\mathrm{CD} 11 \mathrm{~b}^{+} / \mathrm{GR}-1^{-}$positive cells in the lung of $\mathrm{lal}^{+/+}$and $\mathrm{lal}^{-1-}$ mice at 1,3 , and 6 months old from five independent experiments $(n=5)$. Results are mean $\pm \mathrm{SD},{ }^{*} P<0.05$; ${ }^{* * *} P<0.01$. C: H\&E staining of the lung in $\mathrm{lal}^{+/+}$and $\mathrm{lal}^{-1-}$ mice (original magnification, $\times 200$ ). Alveolar lumen was filled with inflammatory cells. D: Kwik-Diff staining of the same amount of bronchioalveolar larvage fluid from $\mathrm{lal}^{+/+}$and $\mathrm{lal}^{-/}$mice (original magnification, $\times 400)$. Both macrophages and neutrophils were increased. Arrows point to neutrophils. mice were macrophages and neutrophils (Figure 5D). Therefore, myeloid cells were able to infiltrate into the terminal organs including the $|a|^{-1-} l u n g$, contributing to regional pathological events.

\section{Apoptosis and Cell Proliferation of Myeloid Populations in $\mathrm{lal}^{-1-}$ Mice}

Systemic accumulation of CD $11 b^{+} / \mathrm{GR}-1^{-}$and CD $11 b^{+} /$ GR $-1^{+}$myeloid cells in $/ a l^{-1-}$ mice can be due to decreased apoptosis or increased cell proliferation and thus, annexin $\mathrm{V}$ staining and BrdU labeling studies were performed in coupling with cell-specific markers. As

A

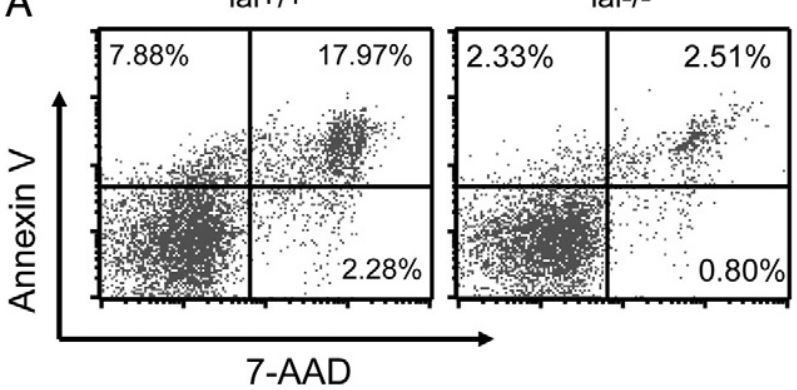

B
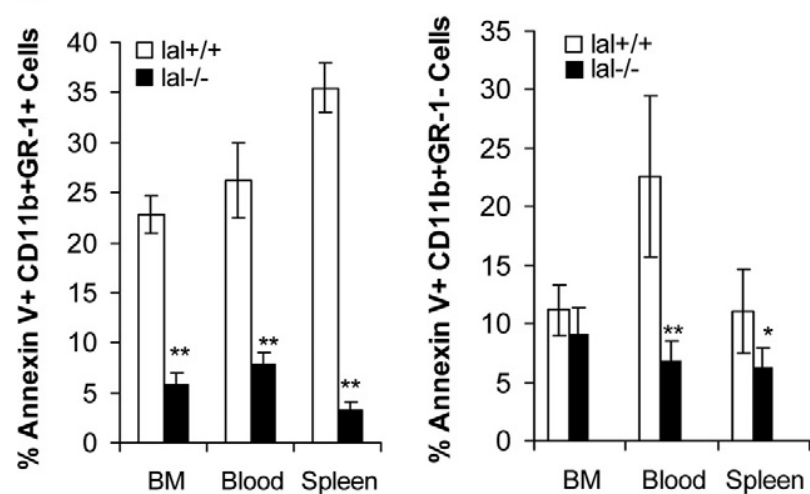

C
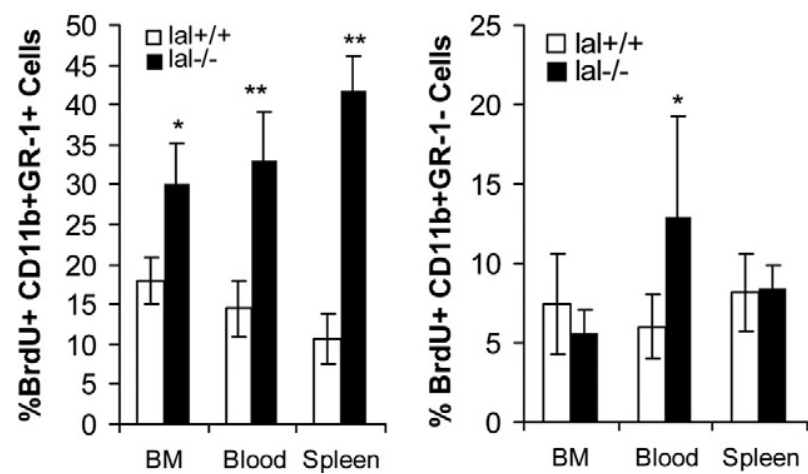

Figure 6. Apoptotic inhibition of myeloid cells in $\mathrm{lat}^{-1}$ mice. A: Representative Annexin V staining in $\mathrm{CD} 11 \mathrm{~b}^{+} / \mathrm{GR}-1^{+}$cells of the bone marrow from 3-month-old $\mathrm{lal}^{+/+}$and $\mathrm{lal}^{-1-}$ mice. B: The percentage numbers of Annexin $\mathrm{V}^{+} \mathrm{CD} 11 \mathrm{~b}^{+} / \mathrm{GR}-1^{+}$cells or $\mathrm{CD} 11 \mathrm{~b}^{+} / \mathrm{GR}-1^{-}$cells in the bone marrow, blood, and spleen from four independent experiments $(n=4)$. Results were mean $\pm \mathrm{SD},{ }^{*} P<0.05 ;{ }^{* *} P<0.01$. C: The percentage numbers of $\mathrm{BrdU}^{+} \mathrm{CD} 11 \mathrm{~b}^{+} / \mathrm{GR}-1^{+}$cells or $\mathrm{CD} 11 \mathrm{~b}^{+} / \mathrm{GR}-1^{-}$cells in the bone marrow, blood, and spleen from four independent experiments $(n=4)$. Results were mean $\pm \mathrm{SD},{ }^{*} P<0.05 ;{ }^{* * *} P<0.01$. 
Table 1. Expression of Intracellular Signaling Molecules in Myeloid Cells (\%) from $l a l^{+/+}$and $l a l^{\prime-}$ Mice

\begin{tabular}{|c|c|c|c|c|c|c|c|c|}
\hline \multirow[b]{2}{*}{ Molecules } & \multicolumn{2}{|c|}{ Bone marrow } & \multicolumn{2}{|c|}{ PBMC } & \multicolumn{2}{|c|}{ Spleen } & \multicolumn{2}{|c|}{ Lung } \\
\hline & $\begin{array}{l}\text { CD11b }{ }^{+} \\
\text {GR-1 }\end{array}$ & $\begin{array}{l}\text { CD11 } b^{+} \\
\text {GR-1 }^{-}\end{array}$ & $\begin{array}{l}\text { CD11b }{ }^{+} \\
\text {GR-1 }\end{array}$ & $\begin{array}{l}\text { CD11 } b^{+} \\
\text {GR-1 }\end{array}$ & $\begin{array}{l}\text { CD11b }{ }^{+} \\
\text {GR-1 }\end{array}$ & $\begin{array}{l}\text { CD11b }{ }^{+} \\
\text {GR-1 }\end{array}$ & $\begin{array}{l}\text { CD11b }{ }^{+} \\
\text {GR-1 }^{+}\end{array}$ & $\begin{array}{l}\text { CD11 } b^{+} \\
\text {GR-1 }\end{array}$ \\
\hline \multicolumn{9}{|l|}{ PU.1 } \\
\hline$|a|^{+/+}$ & $1.0 \pm 0.1$ & $0.6 \pm 0.3$ & $0.8 \pm 0.06$ & $1.0 \pm 0.6$ & $1.2 \pm 0.6$ & $0.5 \pm 0.5$ & $1.5 \pm 0.6$ & $3.7 \pm 1.1$ \\
\hline 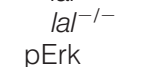 & $12.2 \pm 1.2$ & $2.3 \pm 0.8$ & $3.2 \pm 0.9$ & $9.3 \pm 1.7$ & $10.0 \pm 1.7$ & $12.6 \pm 2.9$ & $7.4 \pm 2.1$ & $27.0 \pm 5.0$ \\
\hline$|a|^{+/+}$ & $1.4 \pm 0.2$ & $1.9 \pm 0.4$ & $1.9 \pm 0.5$ & $2.8 \pm 0.9$ & $1.5 \pm 0.3$ & $0.7 \pm 0.3$ & $1.4 \pm 0.8$ & $2.1 \pm 0.9$ \\
\hline $\begin{array}{l}l^{l a l^{-1-}} \\
\mathrm{pP} 38\end{array}$ & $25.2 \pm 7.9$ & $17.8 \pm 1.6$ & $40 \pm 13.4$ & $17.2 \pm 3.6$ & $68.7 \pm 6.9$ & $29.8 \pm 4.7$ & $61.4 \pm 9.8$ & $13.8 \pm 1.9$ \\
\hline$|\mathrm{al}|^{+/+}$ & $1.1 \pm 0.4$ & $1.6 \pm 0.5$ & $1.9 \pm 0.7$ & $1.2 \pm 0.8$ & $0.7 \pm 0.2$ & $0.9 \pm 0.6$ & $2.6 \pm 0.8$ & $2.1 \pm 0.4$ \\
\hline $\begin{array}{c}l^{l a l^{-1-}} \\
\text { pStat3 }\end{array}$ & $31.2 \pm 8.1$ & $17.2 \pm 3.3$ & $43.9 \pm 7.7$ & $14.9 \pm 2.9$ & $63.5 \pm 9.6$ & $33.9 \pm 12.3$ & $42.5 \pm 12.3$ & $12.2 \pm 2.9$ \\
\hline$|\mathrm{al}|^{+/+}$ & $1.9 \pm 0.4$ & $1.4 \pm 0.3$ & $2.2 \pm 0.3$ & $1.3 \pm 0.4$ & $2.0 \pm 0.6$ & $3.2 \pm 1.2$ & $2.1 \pm 0.9$ & $3.3 \pm 1.5$ \\
\hline$|\mathrm{a}|^{-1-}$ & $42.1 \pm 14.3$ & $18.3 \pm 5.3$ & $75.6 \pm 12.6$ & $13.2 \pm 2.7$ & $66.9 \pm 11.7$ & $28.7 \pm 1.9$ & $27.9 \pm 9.7$ & $15.4 \pm 3.9$ \\
\hline
\end{tabular}

$\mid \mathrm{al} \mathrm{l}^{+/+}$indicates wild-type control mice; $|\mathrm{al}|^{-/-}$, LAL knockout mice. Cells from the bone marrow, blood, spleen, and lung were stained with CD11b and GR-1 antibodies, followed by intranuclear staining of signaling molecules PU.1, pErk, pP38, and pStat3 as described in Materials and Methods. Percentages of PU.1, pErk, pP38, and pStat3-positive cells in CD11 $\mathrm{b}^{+} / \mathrm{GR}-1^{+}$and CD11 $\mathrm{b}^{+}$myeloid cells represent three independent experiments $(n=3)$. Values are means \pm SD.

demonstrated in Figure $6 \mathrm{~A}$ and $\mathrm{B}$, Annexin $\mathrm{V}$ staining was significantly decreased in both $\mathrm{CD} 11 \mathrm{~b}^{+} / \mathrm{GR}-1^{-}$and $\mathrm{CD} 11 \mathrm{~b}^{+} / \mathrm{GR}-1^{+}$myeloid cells from the bone marrow, blood and spleen of $l a l^{-1-}$ mice compared with those from $|a|^{+/+}$mice. This suggests that LAL deficiency inhibited apoptosis in CD11 $\mathrm{b}^{+} / \mathrm{GR}-1^{-}$and $\mathrm{CD} 11 \mathrm{~b}^{+} / \mathrm{GR}-1^{+}$ myeloid cells. When intrinsic proliferation was tested, incorporation of BrdU into CD11 $\mathrm{b}^{+} / \mathrm{GR}-1^{+}$myeloid cells from the bone marrow, blood and spleen of $\mathrm{lal}^{-1-}$ mice was significantly increased (Figure 6C). Increased BrdU incorporation was only observed in $\mathrm{CD}_{11 \mathrm{~b}^{+} / \mathrm{GR}-1^{-}}$ monocytes in the blood. Together, these studies clearly showed that overaccumulation of myeloid cells in $\mid \mathrm{al}^{-{ }^{-}}$ mice is due to inhibition of programed cell death and stimulation of cell proliferation.

It has been reported that Ets family member PU.1 plays a dictating role for commitment of hematopoietic stem cells to myeloid cells. ${ }^{16}$ To elucidate the mechanism that facilitate commitment of $\mathrm{CD} 11 \mathrm{~b}^{+} / \mathrm{GR}-1^{-}$and $\mathrm{CD}_{11 \mathrm{~b}^{+} /}$ GR- $1^{+}$myeloid cells in lal ${ }^{-1-}$ mice, PU. 1 expression was investigated in the bone marrow, blood, spleen, and lung of 3-month-old $\mathrm{lal}^{+/+}$and $\left.\mathrm{lal}\right|^{-1-}$ mice by costaining with PU.1 and cell surface-specific CD11b and Gr-1 antibodies. The percentage number of PU.1-positive cells was significantly increased in gated $\mathrm{CD} 11 \mathrm{~b}^{+} / \mathrm{GR}-1^{-}$and CD $11 \mathrm{~b}^{+} / \mathrm{GR}-1^{+}$myeloid cells in $\mid \mathrm{al}^{-1-}$ (Table 1$)$. Molecules that are known to stimulate cell proliferation were also investigated by costaining with anti-phosphor-Erk or p38 or pStat3 and cell surface-specific CD11b and Gr-1 antibodies. The percentage numbers of phosphor-Erk, P38, and Stat3-positive cells were significantly increased in gated $\mathrm{CD}_{11} \mathrm{~b}^{+} / \mathrm{GR}-1^{-}$and $\mathrm{CD} 11 \mathrm{~b}^{+} / \mathrm{Gr}-1^{+}$myeloid cells of multiple $\mathrm{al}^{-1-}$ tissues (Table 1). The observation has been confirmed by MFI studies (supplemental Table 1, see $h$ ttp://ajp.amjpathol.org).

\section{Bone Marrow Transplantation of lal ${ }^{-/-}$Mice}

To prove that the CD $11 \mathrm{~b}^{+} / \mathrm{GR}-1^{-}$and $\mathrm{CD} 11 \mathrm{~b}^{+} / \mathrm{GR}-1^{+}$ myeloid cell overaccumulation is cell autonomous or at- tributable to changes in tissue microenvironments that affect progenitor cell development, bone marrow cells from $\mathrm{Ial}^{+/+}$and $\mathrm{lal} \mathrm{I}^{-1-}$ mice (CD45.2) were transplanted into reciprocal $\mathrm{Ial}^{+/+}$and $\mathrm{lal}{ }^{-/-}$recipient mice (CD45.1) that were lethally irradiated to generate bone marrow chimeric mice. CD $11 \mathrm{~b}^{+} / \mathrm{GR}-1^{-}$and CD11 $\mathrm{b}^{+} / \mathrm{GR}-1^{+}$myeloid cells in recipient mice were analyzed by gating with CD45.2 antigen that was derived from donor bone marrow cells by flow cytometry with Gr-1 and CD11b antibody staining. The analysis revealed that the donor CD $11 b^{+} / \mathrm{GR}_{-} 1^{-}$and $\mathrm{CD} 11 \mathrm{~b}^{+} / \mathrm{GR}-1^{+}$myeloid cell population in the bone marrow, blood, spleen, and lung of wild-type mice that were received $\mathrm{lal}^{-1-}$ bone marrowtransplanted cells were much higher than those received $|\mathrm{al}|^{+/+}$bone marrow-transplanted cells (Figure 7, A and B). In addition, the CD $11 \mathrm{~b}^{+} / \mathrm{GR}-1^{-}$and $\mathrm{CD} 11 \mathrm{~b}^{+} / \mathrm{GR}-1^{+}$ myeloid cell population in $\mid \mathrm{al}^{-1-}$ recipient mice that were transplanted with $\mathrm{lal}^{+l_{+}}$bone marrow cells was also higher than those in $\mid \mathrm{al} \mathrm{I}^{+/+}$to $\mathrm{Ial}^{+/+}$transplanted mice, except for those in the bone marrow (no statistical significance). These results suggest that both myeloid precursor cell autonomous and alterations in certain tissue microenvironments are present in $\mid \mathrm{la}^{-/-}$mice and are important factors for abnormal $\mathrm{CD} 11 \mathrm{~b}^{+} / \mathrm{GR}-1^{-}$and $\mathrm{CD} 11 \mathrm{~b}^{+} / \mathrm{GR}-1^{+}$myeloid cell emergence, proliferation, and survival.

\section{Discussion}

Although the pathogenic roles of neutral lipids in many diseases have been reported and elucidated, little is known about their functions on myeloid cell development, differentiation, and homeostasis. In this report, we investigated the mechanism responsible for massive expansion of myeloid cells at multiple hematopoietic stages in $|\mathrm{al}|^{-1-}$ mice. Based on our observations, dysregulated bone marrow progenitor cell differentiation is a primary cause for expansion of $/ \mathrm{al}^{-1-}$ myeloid cells. This is attributed to both cell-autonomous and environmental factors. 
A

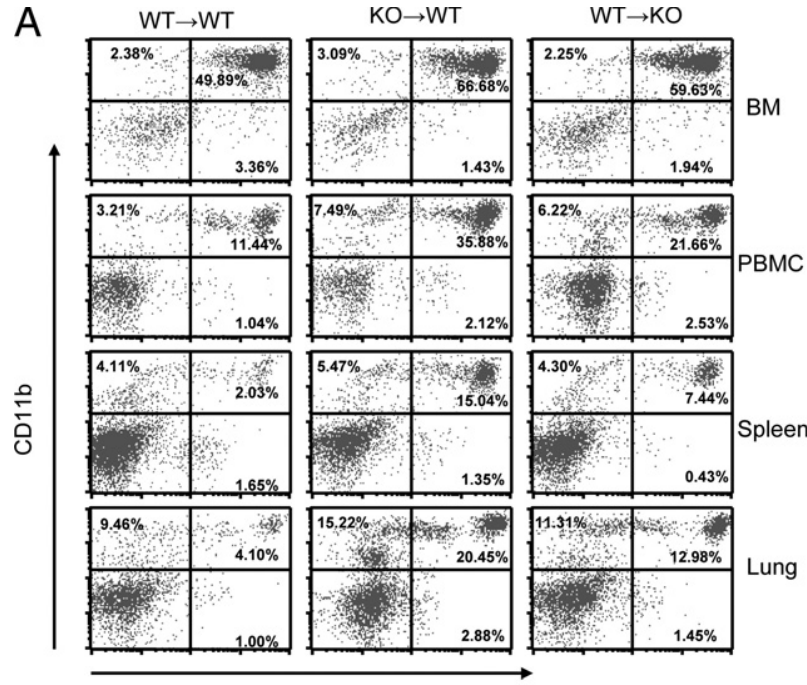

B

BM

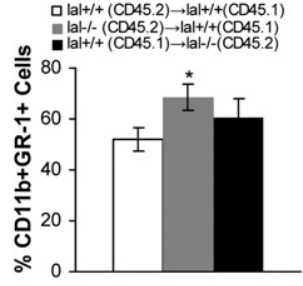

a $\mathrm{lal}+++(\mathrm{CD} 45.2) \rightarrow \mathrm{lal}+++$ (CD45.1)

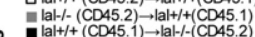

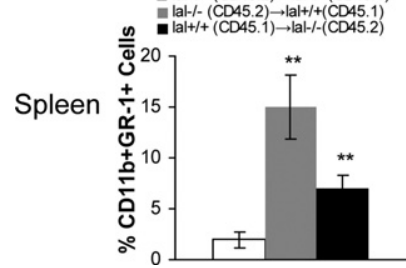

Lung
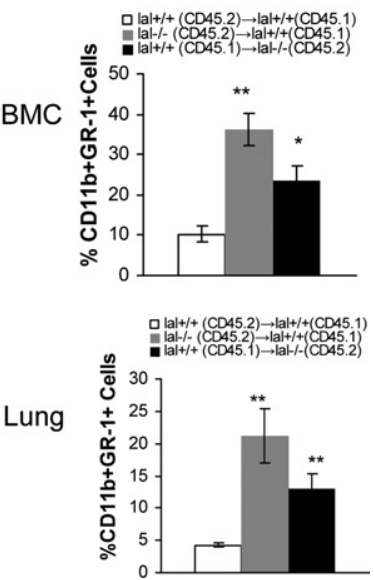

Figure 7. Systemic expansion and accumulation of myeloid cells in $\mathrm{lat}^{-1}$ bone marrow chimeric mice. A: Representative FACS analysis of bone marrow (BM), peripheral blood (PBMC), spleen, and lung cells from $\mathrm{lal}^{+/+}$and $\mathrm{lal}^{-1-}$ bone marrow-transplanted recipient mice by CD11b and GR-1 antibody staining. B: Statistic analyses of donor $\mathrm{CD} 11 \mathrm{~b}^{+} / \mathrm{GR}-1^{+}$myeloid cell populations in $\mathrm{lal}^{+/+}$and $\mathrm{lal}^{-1}$ bone marrow-transplanted recipient mice. Values were derived from four mice in each group $(n=4)$. Results are mean $\pm \mathrm{SD},{ }^{*} P<00.05 ;{ }^{* * *} P<0.01$.

Myeloid cell autonomous defect was evident by abnormal activation of multiintracellular signaling molecules as a result of LAL deficiency (Table 1). For example, PU.1 transcription factor is usually expressed in progenitor cells and is dramatically down-regulated in mature cells. High level expression of PU.1 suggests that myeloid cells are retarded at the immature stage from further differentiated into more mature neutrophils and monocytes/macrophages during LAL deficiency. Because these signaling molecules have profound biochemical and biological functions in cell proliferation, differentiation, and apoptosis, activation of these pathways may sustain myeloid cell growth, migration, and pathogenesis. Malformed myeloid cells exhibited malfunction with stronger suppression on $\mathrm{T}$ cell proliferation and function in $/\left.\mathrm{a}\right|^{-1-}$ mice (Figure 3E). When $\mathrm{lal}^{-1-}$ bone marrow cells were transplanted into wild-type mice, the donor CD $11 b^{+} / \mathrm{GR}-1^{-}$and CD $11 b^{+} /$ GR $-1^{+}$myeloid cell populations in the bone marrow, blood, spleen, and lung of recipient mice were ex- panded. These results suggest that myeloid precursor cell autonomous is critical for myelopoiesis in $/ \mathrm{al}^{-1-}$ mice.

In addition to the intrinsic progenitor problem, the environment in $\mathrm{lal}^{-1-}$ mice also contributes to myeloid cell hyperexpansion, because the donor CD11 b $/ \mathrm{GR}-1^{+} \mathrm{my}-$ eloid cell population in $\mathrm{al}^{-1-}$ recipient mice that were transplanted with wild-type bone marrow cells was expanded. As we reported previously, LAL deficiency causes malformation and malfunction in many tissues, including the adult liver, lung, spleen, thymus, adrenal glands, and small intestine. ${ }^{3-6,9}$ These environmental changes are able to influence myelopoiesis. For example, the Affymetrix GeneChip microarray study identified overexpression of matrix metalloproteinase 12 (MMP12) gene in the lung. When MMP12 was overexpressed in lung epithelial cells of the CCSP-rtTA/(TetO) $)_{7}-\mathrm{CMV}$ MMP12 bitransgenic mouse model to mimic MMP12 overexpression in $\mid \mathrm{ll}^{-1-}$ mice, MDSC expansion with immunosuppression of $\mathrm{T}$ cells were observed. As a consequence, MMP12-induced inflammation directly led to spontaneous emphysema and lung cancer. ${ }^{20}$ This example clearly demonstrates that changes in $|a|^{-1-}$ tissue environments influence myelopoiesis.

One mechanism for LAL deficiency-mediated hyperexpansion of myeloid cells in $/\left.a\right|^{-1-}$ mice is upregulation of apoptosis inhibitor 6 (Api6). Api6 is regulated by LAL metabolic derivatives (e.g., 9-HODE) and lipid mediator peroxisome proliferator-activated receptor gamma (PPAR $\gamma)^{7}$ Api6 was originally identified as a secreted protein from macrophages and belongs to the macrophage scavenger receptor cysteine-rich domain superfamily. ${ }^{21,22}$ Api6 has been implicated to play a very important role in regulating immune cells. Based on observation made in $\mid \mathrm{al}^{-1-}$ mice, a myeloid-specific c-fms-rtTA/(TetO) $)_{7}-\mathrm{CMV}$ Api6 bitransgenic mouse model under the control of the c-fms promoter/intron 2 was created. ${ }^{8}$ In this bitransgenic system, Api6 was expressed specifically in myeloid lineage cells after doxycycline treatment in an inducible manner. Many phenotypes in this animal model were similar to those observed in $|a|^{-1-}$ mice. For example, induction of Api6 abnormally elevated myeloid cells in the bone marrow, blood, and lung in vivo. CD11 $\mathrm{b}^{+} / \mathrm{Gr}-1^{+}$ myeloid cells were systemically increased with increased cell proliferation and decreased apoptosis activities. Api6 overexpression activated intracellular signaling pathways including Stat3, Erk1/2, and P38 in myeloid lineage cells in bitransgenic mice. As a result, persistent inflammation in c-fms-rtTA/(TetO) $)_{7}$-CMV-Api6 bitransgenic mouse model caused hypercellularity and adenocarcinoma in the lung. ${ }^{8}$

In contrast to myeloid lineage cells, LAL deficiency blocked CLP development in the bone marrow. This directly affected lymphopoiesis in $/ \mathrm{al}^{-1-}$ mice as we recently reported..$^{9}$ In $/ a l^{-1-}$ mice, LAL deficiency led to abnormal organization of the thymus and spleen structures. LAL deficiency impaired progression of $T$ cell development in the thymus and retarded maturation of peripheral T cells. $\mathrm{Lal}^{-1-} \mathrm{T}$ cells lost ability in responding to $T$ cell receptor stimulation, including reduced expression of cell surface receptor CD69, abolishment of T cell proliferation, the decreased expression of $T$ lymphokines 
after stimulation by anti-CD3 plus anti-CD28, or phorbol12-myristate-13-acetate (PMA) and Ionomycin. Differentiation of Th1 and Th2 CD4 ${ }^{+}$effector lymphocytes by T cell receptor stimulation was blocked in $|a|^{-1-}$ mice. The ratio of $\mathrm{CD} 4^{+} \mathrm{CD} 25^{+} \mathrm{FoxP} 3^{+}$Treg to $\mathrm{CD} 4^{+} \mathrm{T}$ cells was increased in the $\mathrm{lal}^{-1-}$ spleen. Bone marrow chimeras demonstrated retardation of T cell development and maturation in $\mid \mathrm{al}^{-1-}$ mice attributable to the defects in lymphoid progenitors. Interestingly and importantly, massive myeloid cell infiltration in the thymus and spleen was observed in $\mid \mathrm{al}^{-1-}$ mice. ${ }^{9}$ As demonstrated in this report (Figure $3 \mathrm{E}$ ), accumulation of abnormal myeloid cells is detrimental to $\mathrm{T}$ cell proliferation, maturation, and function in $|a|^{-1-}$ mice. Together, the altered development and function of $\mathrm{lal}^{-1-}$ myeloid and lymphoid cells contributes to disease formation in various organs during $L A L$ deficiency.

\section{Acknowledgments}

We thank Marjorie E. Albrecht and Jingxin Jin for assisting with tissue collection and treatment and Dr. Xuemei Lian for Kwik Diff staining.

\section{References}

1. Weissman IL, Shizuru JA: The origins of the identification and isolation of hematopoietic stem cells, and their capability to induce donorspecific transplantation tolerance and treat autoimmune diseases. Blood 2008, 112:3543-3553

2. Blank U, Karlsson G, Karlsson S: Signaling pathways governing stemcell fate. Blood 2008, 111:492-503

3. Lian X, Yan C, Yang L, Xu Y, Du H: Lysosomal acid lipase deficiency causes respiratory inflammation and destruction in the lung. Am J Physiol Lung Cell Mol Physiol 2004, 286:L801-L807

4. Du H, Heur M, Duanmu M, Grabowski GA, Hui DY, Witte DP, Mishra J: Lysosomal acid lipase-deficient mice: depletion of white and brown fat, severe hepatosplenomegaly, and shortened life span. J Lipid Res 2001, 42:489-500

5. Du H, Duanmu M, Witte D, Grabowski GA: Targeted disruption of the mouse lysosomal acid lipase gene: long-term survival with massive cholesteryl ester and triglyceride storage. Hum Mol Genet 1998, 7:1347-1354

6. Yan C, Lian X, Li Y, Dai Y, White A, Qin Y, Li H, Hume DA, Du H: Macrophage-Specific Expression of Human Lysosomal Acid Lipase
Corrects Inflammation and Pathogenic Phenotypes in lal-/- Mice. Am J Pathol 2006, 169:916-926

7. Lian X, Yan C, Qin Y, Knox L, Li T, Du H: Neutral lipids and peroxisome proliferator-activated receptor-\{gamma\} control pulmonary gene expression and inflammation-triggered pathogenesis in lysosomal acid lipase knockout mice. Am J Pathol 2005, 167:813-821

8. Qu P, Du H, Li Y, Yan C: Myeloid-specific expression of Api6/AIM/Sp alpha induces systemic inflammation and adenocarcinoma in the lung. J Immunol 2009, 182:1648-1659

9. Qu P, Du H, Wilkes DS, Yan C: Critical roles of lysosomal acid lipase in T cell development and function. Am J Pathol 2009, 174:944-956

10. Orschell CM, Borneo J, Munugalavadla V, Ma P, Sims E, Ramdas B, Yoder MC, Kapur R: Deficiency of Src family kinases compromises the repopulating ability of hematopoietic stem cells. Exp Hematol 2008, 36:655-666

11. Yoder MC, Du XX, Williams DA: High proliferative potential colonyforming cell heterogeneity identified using counterflow centrifugal elutriation. Blood 1993, 82:385-391

12. Li W, Johnson SA, Shelley WC, Ferkowicz M, Morrison P, Li Y, Yoder MC: Primary endothelial cells isolated from the yolk sac and paraaortic splanchnopleura support the expansion of adult marrow stem cells in vitro. Blood 2003, 102:4345-4353

13. Lux CT, Yoshimoto M, McGrath K, Conway SJ, Palis J, Yoder MC: All primitive and definitive hematopoietic progenitor cells emerging before E10 in the mouse embryo are products of the yolk sac. Blood 2008, 111:3435-3438

14. Palis J, Chan RJ, Koniski A, Patel R, Starr M, Yoder MC: Spatial and temporal emergence of high proliferative potential hematopoietic precursors during murine embryogenesis, Proc Natl Acad Sci U S A 2001, 98:4528-4533

15. Lagasse E, Weissman IL: Flow cytometric identification of murine neutrophils and monocytes. J Immunol Methods 1996, 197:139-150

16. Dahl R, Walsh JC, Lancki D, Laslo P, lyer SR, Singh H, Simon MC: Regulation of macrophage and neutrophil cell fates by the PU. 1:C/ EBPalpha ratio and granulocyte colony-stimulating factor. Nat Immunol 2003, 4:1029-1036

17. Gabrilovich DI, Nagaraj S: Myeloid-derived suppressor cells as regulators of the immune system. Nat Rev Immunol 2009, 9:162-174

18. Ostrand-Rosenberg S, Sinha P: Myeloid-derived suppressor cells: linking inflammation and cancer. J Immunol 2009, 182:4499-4506

19. Sica A, Bronte V: Altered macrophage differentiation and immune dysfunction in tumor development. J Clin Invest 2007, 117:1155-1166

20. Qu P, Du H, Wang X, Yan C: Matrix metalloproteinase 12 overexpression in lung epithelial cells plays a key role in emphysema to lung bronchioalveolar adenocarcinoma transition. Cancer Res 2009, 69:7252-7261

21. Gebe JA, Llewellyn M, Hoggatt H, Aruffo A: Molecular cloning, genomic organization and cell-binding characteristics of mouse Spalpha. Immunology 2000, 99:78-86

22. Miyazaki T, Hirokami $Y$, Matsuhashi N, Takatsuka H, Naito M: Increased susceptibility of thymocytes to apoptosis in mice lacking AIM, a novel murine macrophage-derived soluble factor belonging to the scavenger receptor cysteine-rich domain superfamily. J Exp Med 1999, 189:413-422 